\title{
Transaction Costs and Evolution of New Institutions in Farmers' Managed Irrigation System in $\mathrm{Nepal}^{1}$
}

\author{
Dr. Ram Chandra Bhattarai ${ }^{2}$ \\ Tara Prasad Bhusal
}

\begin{abstract}
The paper examines the impact of transaction costs on institutional development and agricultural productivity in Nepal and analyzes the factors influencing transaction costs. A field survey of in the Kathmandu and Palpa districts of Nepal, reveals that transaction costs amount to $3 \%$ of the net farm return and $3.3 \%$ of the total cost of production. It is rational for farmers to invest in ensuring reliable irrigation and better institutional management because farmers with reliable irrigation and better institution reported higher productivity.
\end{abstract}

Keywords: transaction costs, irrigation system, institution, management,farmers

\section{INTRODUCTION}

Agriculture is the main source of livelihood for a majority of people in developing countries. In Nepal, it not only contributes about one third of the GDP but also provides employment for more than two thirds of the population (MOF, 2015). However, improvements in rural incomes crucially depend on productivity-enhancing infrastructure, irrigation being one of them. According to estimates, about 1.8 million ha of land in Nepal is irrigable. However, currently, only 1.2 million ha of this area is under irrigation although the facility is not available even for this land throughout the year. The total irrigated area, as a \% of the total cultivable area in Nepal, is only $28 \%$ (NPC, 2011). In Nepal, both the state and the farmers play a role in creating and maintaining irrigation infrastructure. In areas where irrigation is by surface water through gravity flow, it needs either community or state involvement for both proper maintenance and for equitable water distribution.

Irrigation has typical common pool resource features of non-excludability and rivalry. While it may be difficult to exclude any farmer in the command area from utilizing

1 The paper is the outcome of the research on Transaction cost and evolution of new institutions in Farmer's Managed Irrigation System in Nepal, with the support of University Grant Commission. We want to thank University Grants Commission for providing support for the research work. The authors are also thankful to Dr. Nayan Krishna Joshi for his valuable inputs on the paper.

2 Dr. Bhattarai is Professor of Economics at Department of Economics, Patan Multiple Campus, Tribhuvan University, Nepal. Dr. Bhattarai is available at bhattarai.ramchandra@gmail.com

3 Tara Prasad Bhusal is Associate Professor of Economics at Central Department of Economics, Tribhuvan University Nepal. Mr. Bhusal is available at tarabhusal777@gmail.com 
irrigation water, its use upstream will indubitably reduce its availability to those living downstream of the canal. Thus, water allocation and provisioning are two potential problems associated with the management of irrigation systems (Ostrom, 1990). However, the operation and maintenance of an irrigation system requires coordination among many farmers. Unfortunately, resource management is riddled with conflicts and free-rider problems which often result in poor maintenance (Tang, 1992). Solutions to such problems lie in either a strong institutional mechanism operated by the state or collective action.

The institutional development of collectively managed irrigation systems assumes importance in such a context. Institutional development, however, has a symbiotic relationship with transaction costs. Although analyses of institutions typically associate efficiency with lower transaction costs (Ostrom, 2005), in situations where institutions are still evolving, a higher transaction cost may lead eventually to a more efficient and robust institution whereas a lower transaction cost may result in a weak or dysfunctional institution. As institutions evolve, transactions costs may change depending on the existing state of cooperation. Among the factors that influence successful collective action are homogeneity, prior history of collective action, size of group, resource, and costs and benefits of cooperation (Agrawal, 2001; Bardhan, 2005; Sethi \& Somanathan, 2006).

Nepal has approximately 16,000 Farmer-Managed Irrigation Systems (FMIS) which irrigate approximately 714,000 ha (i.e., $67 \%$ of the total irrigable area) of the country (Pradhan, 2002; Lam, 1998; Shivakoti, 2007). Since irrigation development has been a community level concern given the nature of the terrain in the hill tracts, it is important to understand how transactions costs influence agricultural productivity. With this objective in mind, we adopt an econometric model in this study to analyze the relationship between transaction costs and productivity.

Four key factors in natural resource management influence transactions costs: uncertainty, asset specificity, frequency of decision-making, and care or effort intensity (Williamson, 1991). Uncertainty about a resource, which could be due to natural factors (such as natural disasters, timing of monsoons, etc.) or man-made factors (such as security of property rights, etc.), can result in high levels of transaction costs. Similarly, the frequency of decision-making could raise transaction costs since transaction requires time, ranging from daily to seasonal, and resource commitment from involved agents (Birner \& Wittmer, 2004). Asset specificity, on the other hand, describes the investment in physical assets that are essential in a particular transaction for the production and use of the resource (Birner \& Wittmer, 2004). In the case of 
effort- and care-intensive transactions, the former describes production activity while the latter describes protection activity (Fenoaltea, 1984).

Transactions costs exist at several resource management stages: description of the resource use context, regulatory design, and implementation of agreed rules (Hanna, 1995). In the case of community-based resource management of irrigation water, farmers incur costs in the form of negotiation, in monitoring activities related to the institutional design, in maintenance of the organization, and enforcement of rights over the water. We therefore classify the transaction cost into two broad categories, ex-ante and ex-post costs, which we in turn divide into five broad activities: (i) watching, waiting and negotiating (WWN), (ii) meeting, (iii) conflict resolution, (iv) communication, and (v) formation costs. While WWN and "conflict resolution" are ex-post transaction costs, "communication" and "formation" are ex-ante transaction costs. Meeting costs, depending on the nature of the meeting, could be either ex-ante or ex-post. If the existing institutional structure changes, the transaction cost structure may also change. Co-management has the potential to increase the ex-ante transaction costs although it may also result in a reduction in ex-post transaction costs (Kuperan et al., 1998).

Previous studies have shown that transaction costs can vary across regions and sectors. In Kenya, transaction costs of landowners arising from collaborative wildlife management were relatively low (Mburu et al., 2003) but in the Philippines, monitoring alone accounted for more than $50 \%$ of the total costs of co-management in the fisheries (Kuperan et al., 1998). The transaction costs accounted for 37\% of the total costs in another study from the Philippines of a community-based coastal management program where the share of the transaction cost was as high as $74 \%$ of the total cost in the implementation phase (Sumalde \& Pedroso, 2001).

Adhikari and Lovett (2006) found transaction costs to be a major component of resource management costs in the community forestry sector ranging between $9-14 \%$ of the total cost in Nepal. Another study based on two irrigation systems located within the Kathmandu Valley distinguished between the conveyance and congestion costs for canal maintenance. When the conveyance cost of water was high, all farmers paid the maintenance fee regularly, but when upstream farmers showed reluctance to cooperate with downstream farmers, congestion costs became important and farmers paid more for WWN (Osanami \& Joshi, 2005). Bhattarai (2011) estimated the transaction costs in FMIS in Nepal based on a case study of 60 irrigated systems in Kathmandu Valley. The findings show that the main elements of transaction costs are the time spent on watching, waiting and negotiating over the water use. Time spent on transactions is 
relatively low for FMIS, accounting to $5 \%$ of the total time costs for the production of crops.

This paper analyzes the impact of transaction costs on institutional development in Nepal's FMIS, which existing studies have not attempted.

\section{RESEARCH METHODOLOGY}

\section{Study Area}

Two districts, one Kathmandu, located at central development region and the other Palpa, located at western development region were selected for the purpose of the study. Total population of Kathmandu District is about 1.7 million of which about $60 \%$ reside within urban centers and about $40 \%$ reside in the countryside. Annual growth rate of Kathmandu district is 4.76 during 2001-2011 (CBS, 2010; 2011). Similarly total population of Palpa District is only about 0.27 million, about $90 \%$ of the total population reside in rural area and only $10 \%$ population reside in urban centre. The growth rate of population during 2001-2011 is only $0.03 \%$ (CBS, 2011). Total cultivable area in Kathmandu is 11,914 hectare (ha.) and in Palpa 28,714 ha.. The major cereal crops in these two districts are paddy, wheat, maize and millet. Potato, oilseed and vegetables are the major cash crops. Among these crops paddy, wheat, potato and vegetables need irrigation water.

\section{Sampling Frame and Data Collection}

As a first step, we listed all the irrigation system within these two districts. About 191 systems are listed in Kathmandu districts. Most of them are working and providing irrigation to the cultivable land of Kathmandu. However, some of them are not in function due to the urbanization and massive land plotting in Kathmandu. In Palpa about 40 systems are found in the record of the District Irrigation Water Users Association office. These systems irrigate the land from 3 hectare to 209 hectare land. Six systems from Kathmandu districts and five from Palpa district are selected with purposive sampling for the detail field work. Ten households from each system are selected with stratified random sampling technique. All systems were divided in up and down stream and equal number of households (5) from each sub-system are selected randomly from the households within the system. The total number of households selected for the study is 108 . Though the number is relatively small it covers all strata i.e. up and down stream and hence it may represent the households of the selected system.

Considering these information, two sets of questionnaire were prepared and pretested in Khokana Raj Kulo of Lalitpur. Revision on the questionnaire was made with 
the outcome of the pre-test. The information from the households and the system was collected with the help of separate structured questionnaires. The system-level questionnaire recorded the characteristics of the Water User Associations (WUA) and the canal system while the household-level questionnaire included questions about the respondent's and household's demographic and socio-economic characteristics and their agricultural practices. It also recorded the time spent on different components of transaction during the two seasons, winter and summer, of the previous year, which was the year 2011. While the survey collected socio-economic information, institutional information, return and cost on farm its main focus was on transaction cost information.Additional information was also gathered with the PRA technique and also from key informants.

\section{Method Adopted to Measure the Transaction Cost}

Transaction costs are incurred by the irrigation water users at both the organization/ system and household levels. System level transaction costs occur both at the ex-post and ex-ante stage (for organization formation). Meetings, registration and negotiation costs are ex-ante in nature as they arise prior to the formation of an organization. Ex-post cost, on the other hand, is the time cost for meetings, conflict resolution and communications (Bhattarai, 2007). We also calculated transaction costs at the household level where we include the cost for watching, waiting and negotiating cost as post organization formation cost but incurred during irrigation management. Methods of estimating transaction costs are given in Table 1.

Table 1: Method of Estimating Annual Transaction Costs

\begin{tabular}{|c|c|c|c|c|}
\hline Transaction & $\begin{array}{l}\text { Nature of } \\
\text { Transaction/ } \\
\text { Elements of } \\
\text { Transaction }\end{array}$ & Nature of Cost & Approach & $\begin{array}{l}\text { Cost } \\
\text { Estimation }\end{array}$ \\
\hline $\begin{array}{l}\text { Formation of } \\
\text { Organization }\end{array}$ & $\begin{array}{l}\text { Meetings/dealing } \\
\text { with stake holders }\end{array}$ & $\begin{array}{l}\text { Time for } \\
\text { Meetings }\end{array}$ & $\begin{array}{l}\text { Value of } \\
\text { time= Wage } \\
\text { rate }^{*} \text { time }\end{array}$ & $\begin{array}{l}\text { Interest rate } \\
\text { as annual cost }\end{array}$ \\
\hline $\begin{array}{l}\text { Formation of } \\
\text { Organization }\end{array}$ & $\begin{array}{l}\text { Dealing with } \\
\text { government offices }\end{array}$ & $\begin{array}{l}\text { Travel cost, } \\
\text { registration } \\
\text { cost, statute } \\
\text { preparation cost }\end{array}$ & $\begin{array}{l}\text { Monetary } \\
\text { Expenditure }\end{array}$ & $\begin{array}{l}\text { Interest rate } \\
\text { as annual cost }\end{array}$ \\
\hline $\begin{array}{l}\text { Ensuring the } \\
\text { implementation } \\
\text { of Decision }\end{array}$ & $\begin{array}{l}\text { Meetings/dealings } \\
\text { with agents/ } \\
\text { communication/ } \\
\text { conflict resolution }\end{array}$ & $\begin{array}{l}\text { Time for } \\
\text { meetings }\end{array}$ & $\begin{array}{l}\text { Wage } \\
\text { rate*time }\end{array}$ & $\begin{array}{l}\text { Opportunity } \\
\text { Cost }\end{array}$ \\
\hline $\begin{array}{l}\text { Protecting and } \\
\text { Negotiating }\end{array}$ & $\begin{array}{l}\text { Watching, Waiting } \\
\text { and Negotiating }\end{array}$ & Time & $\begin{array}{l}\text { Wage } \\
\text { rate }^{*} \text { time }\end{array}$ & $\begin{array}{l}\text { Opportunity } \\
\text { Cost }\end{array}$ \\
\hline
\end{tabular}


Transaction cost estimation involved a direct monetary measurement as well as an imputed one. The direct measure included payments to hired labour for watching and waiting while the imputed costs included contributions in terms of time by members of the household for various activities. To measure the imputed cost of time spent by individuals in organizational work we valued the opportunity cost at the average wage rate of peak and slack season.Association/organization Formation cost is a onetime fixed cost which is calculated on the basis of the time and resources devoted by farmers at the time of formation of the organization/association. Hence the lowest interest rate of the bank for lending was used to estimate the annual transaction cost of formation.

The total annual transaction time was estimated by adding the time incurred by households at the system level as well as at the household level. In order to make these compatible, the system level total annual transaction time was divided by the total number of households within the system and added it to the household level transaction time. In order to avoid the problem of double counting, the general meeting time at the system level was not added to the total transaction time since this was already accounted for in the household's transaction cost estimation. Every 8 hours was considered as one working day to arrive a day measure for time costs.

\section{FINDINGS OF THE STUDY}

\section{Demographic Characteristics}

The total population of the selected household is 619 and the average size of the household is 5.73. The average size of the household in Kathmandu is slightly smaller (5.37) than the average size of Palpa (6.16). It is rational since Palpa have more rural area than Kathmandu and rural population have more household size than urban population.

The average sample household size of both the district is slightly higher than the district average census data (i.e., 3.71 and 4.28 for Kathmand $u$ and Palpa respectively). It may be because of the surveyed household are more rural household who work in the farm whereas the urban household within the district also have lower household size to that of the rural household. Of the total population 326 are male and 293 are female. The male population is slightly higher than the female population. It also may be due to the male dominated society in rural farm households. Of the total Population17 $\%$ are under the age of 14 and about $10 \%$ are above the age of 60 . Thus nearly 24 
$\%$ of the total population is dependent population. About $50 \%$ of the population is economically active population.

About $22 \%$ of the total population were illiterate and about $42 \%$ of the population were SLC or above. However the share of illiterate population in Palpa was $25 \%$ whereas it was only $21 \%$ in Kathmandu. Similarly the people having the education of above SLC are about $44 \%$ in Kathmandu whereas it is only $39 \%$ in Palpa. Among the household head about one third are illiterate.

Major occupation of the household is farming. Among the total population $40 \%$ are engaged in agriculture and one third are students. About $8 \%$ are aged or child whereas about $12 \%$ are engaged in business and salary work. About $6 \%$ are in foreign job. The people engaged in salary and wage work are $12 \%$ Kathmandu whereas they are only $3 \%$ in Palpa. Similarly about $9 \%$ of the total population in Palpa are in foreign job whereas it is only $3 \%$ in Kathmandu.

\section{Organization Structure}

Among the 11 canals of the two districts, 7 canal system have the registered organization. Two of them have no organization. These systems are not functioning properly. Two other systems have informal organization but do not have any committee to govern and manage the organization. Thus there are only seven canal systems which have organized committee and the remaining four have not any committee to govern the canal system. As a registered organization at least two female must be executive members. Hence must of the registered organization have 2 female members in the committee. However, in case of Chherlung Raj Kulo only male members are in the executive committee and in Bishwambhara only one female member is in executive committee.

\section{Construction of the Canals}

Among these six irrigation systems in Kathmandu two were constructed during the Malla period, that is, about 3000 years back, 3 were constructed 100 years back and the one was constructed about 36 years back. Almost all the canals except one were constructed by the ancestors of the user farmers with their contribution of labour. However, one canal i.e. Bishwambhara Raj Kulo, was constructed with the support of Indian Government. They do not have any record of farmer's contribution as these canals were constructed by their ancestors and there is no record of the construction activity. Again during 1970's and first half of 1980's government repaired the canals and managed totally with public resources. Out of five canals in Palpa, two, canals 
were constructed more than 100 years back, two were constructed 70 years back and one was constructed about 45 years back.

\section{Management Provision}

There is a provision of Jimmuwal and Mukhiya ${ }^{4}$. Traditionally Jimmuwal and Mukhiya inform for Jhara ${ }^{5}$ and used to collect the Khara ${ }^{6}$ in three canals of Palpa that is in Chherlung, Jethi Raj Kulo and Maili Raj Kulo. However, after 2022 BS (bikram sambat) the responsibility was given to only Mukhiya. Mukhiya works as the chairman of the canal. Mukhiya is the person who handles the management of the canal. If some farmers need more water they need to request to Mukhiya and he manages the water. For repair and maintenance in Chherlung one share ( 1 inch water) need to contribute one day for canal repair at least twice in a year, which they term the name as Jhara. The individual, who do not contribute Jhara, should pay Khara as penalty. The amount of penalty is Rs 100 in winter and Rs. 70 for the summer. Those who own small share of water will get remuneration for the work in the canal

In Jethi and Maili Raj Kulo one Jhara should be provided as per the 20 Matomuri ${ }^{7}$ Those who do not participate labour to repair the canal Rs. 120 penalty should be paid as Khara. Women are prohibited to participate as Jhara for the repair of the canal. However, women can participate for construction work. Those single women without child should pay Khara. However, single women with child are exempted from Jhara and Khara with the assumption that the baby after grownup can participate in the repair work in the future. Jimmuwal and Mukhiya need not pay Jhara and Khara. Normally the work of Jimmuwal and Mukhiya is being handled by the same family as heredity. Each year in May 28-29 there will be general assembly. In that day all the income and expenditure during a year as well as the participation of Jhara and Khara will be disclosed and penalty amount of Khara for non-participation in Jhara will also be decided and declared. Jimmuwal and Mukhiya will also be elected on the day of general assembly.

4 Jimmuwal and Mukhiyawere authorized to collect the land revenue in the given village area during Rana regime. The same people were authorized to head the canal management committee traditionally.

5 Jharais used for the labour contribution for repair and maintenance of the canal. If the canal damaged by flood and landslides then Mahajhara will be applied. In case of Mahajhara more labour should contribute for the repair and maintenance of the canal.

6 Khara is used for the penalty payment in case of not able to contribute the Jhara as per the rule and regulation of the canal system. The amount of Khara is fixed by the meeting of the users committee.

7 Matomuri is the traditional measure of land area. 1 matomuri is equivalent to 0.0125 ha of land area. 
In case of floods and landslides during rainy season there is a system of contributing labour by all users equally till the completion of work. In such situation there is no equity rather the system is regressive. However, there is no objection by the small land owners till this time. Mukhiya maintain the attendance of such Jhara. The labour contribution in case of floods and landslides is called as Mahajhara. Those who do not participate in the Jhara should pay Khara.

There is no provision of water guard in the studied canals of Palpa. After the completion of repair and maintenance the whole responsibility of the canal will be taken by Mukhiya. Mukhiya will request to Jimmuwal for the allocation of labour by users. Then Jimmuwal will allocate labour for each user as per the ownership of irrigated land. Each water user should participate as water guard to watching, waiting and negotiating in the canal.

There is no provision of Jhara and Khara in Kathmandu. As all the canals were constructed either by their ancestors or by the contribution of the government or donor agency, the present farmers have little or no contribution for the construction of the canal. The farmers are organized and registered just to receive the fund from the government. Most of the canals in Kathmandu get resources for the repair and maintenance of the canal. There is not any system of users' fee payment and there is also not any provision to exclude the nonmembers for the use of the canal.

\section{Cultivation Practices}

In Palpa the land is highly fertile. The farmers cultivate paddy, wheat, maize, potato and vegetables. Similarly in Kathmandu, the farmers cultivate paddy, wheat, maize, vegetables and potato. Agriculture cooperative and other organizations are also existent within the system.

\section{Transaction Cost, Production Cost and Return from the Farm}

Table 2 shows the share of transaction to total production cost and return on the farm. The share of transaction cost to total cost ranges from 2.3 to $6 \%$ and it is highest in case of Palpa whereas it is lowest in case of Kathmandu. In terms of value of output it ranges 1.3 to $2.4 \%$. 
Table 2: Transaction Cost, Production Cost and Value of Output

\begin{tabular}{|c|c|c|c|c|c|c|c|}
\hline Category & $\begin{array}{l}\text { Average } \\
\text { TC per } \\
\text { ha. (NRs) }\end{array}$ & $\begin{array}{l}\text { Average } \\
\text { Prodn. } \\
\text { Cost per } \\
\text { ha (NRs.) }\end{array}$ & $\begin{array}{l}\text { Average } \\
\text { Value of } \\
\text { Output } \\
\text { per ha } \\
\text { (NRs.) }\end{array}$ & $\begin{array}{l}\text { Net return } \\
\text { per hectare } \\
\text { (Average } \\
\text { Value- } \\
\text { Average } \\
\text { Cost) (NRs.) }\end{array}$ & $\begin{array}{l}\text { Share } \\
\text { of TC } \\
\text { to Net } \\
\text { Return } \\
(\text { in } \%)\end{array}$ & $\begin{array}{l}\text { Share } \\
\text { of TC } \\
\text { to total } \\
\text { cost (in } \\
\%)\end{array}$ & $\begin{array}{l}\text { Share of } \\
\text { TC to total } \\
\text { value of } \\
\text { output } \\
\text { in } \%\end{array}$ \\
\hline Kathmandu & 2371 & 101326 & 178088 & 76762 & 3.1 & 2.3 & 1.3 \\
\hline Palpa & 2333 & 38261 & 110694 & 72433 & 3.2 & 6.1 & 2.1 \\
\hline $\begin{array}{l}\text { Water is not } \\
\text { reliable }\end{array}$ & 2337 & 61566 & 98086 & 36520 & 6.4 & 3.8 & 2.4 \\
\hline $\begin{array}{l}\text { Water is } \\
\text { reliable }\end{array}$ & 2363 & 79475 & 178977 & 99502 & 2.4 & 3.0 & 1.3 \\
\hline $\begin{array}{l}\text { Farm located } \\
\text { Up }\end{array}$ & 2402 & 69490 & 151777 & 82287 & 2.9 & 3.5 & 1.6 \\
\hline $\begin{array}{l}\text { Farm Located } \\
\text { down }\end{array}$ & 2305 & 75457 & 142587 & 67130 & 3.4 & 3.1 & 1.6 \\
\hline No free riding & 2333 & 48072 & 139077 & 91005 & 2.6 & 4.9 & 1.7 \\
\hline Yes free riding & 2370 & 86425 & 151899 & 65474 & 3.6 & 2.7 & 1.6 \\
\hline Total & 2355 & 72446 & 147225 & 74779 & 3.1 & 3.3 & 1.6 \\
\hline
\end{tabular}

Source: Field Survey, 2012

The share of transaction cost to total value of output is lowest in case of Kathmandu and is highest in case of farmers with unreliable water. However, such difference may be due to the differences in prices of inputs and output in Kathmandu and in Palpa. Hence to minimize the effect of differences in prices attempt is made to compare the share of transaction cost with net return (Average value of output- Average production cost per hectare). In comparison to the net return the share of transaction cost is lowest when water is more reliable and the share of transaction cost is highest when the water in not reliable. It is not much difference between the districts. When farmers enjoy free riding transaction cost is low and when they control for free riding the share of transaction cost to net return is relatively high. The share of transaction cost to net return is high to those farmers located at downstream of the canal compared to those farmers located in upstream.

There are not many studies on the Transaction Costs in FMIS hence it is hard to say whether the transaction costs estimated under the present analysis is high or low. The 
findings of the present study are however, consistent to Mburi et al. (2003) and Bhattarai (2011) who studied the transaction costs in collaborative wild life management in Kenya and Transaction Costs in FMIS in Kathmandu Valley respectively. However, the findings reveal that the annual transaction cost in FMIS is relatively low compared to community forestry in Nepal. Adhikari et al (2006), for instance, found that the annual transaction cost for a household in community forestry ranges between 9-14 $\%$ of the total cost which is much higher than the present study where, it is just about $3 \%$ in an averages and is below $6 \%$ in all the cases and it is less than 2 percent of the total value of the return.

\section{Econometric Model}

One of the important factor that determine the productivity of farms is the availability of water at the farm level, which in turn is determined by the existence of canal and maintenance and operation status (Bhattarai, 2011). There is high uncertainty in the water flow of irrigation and this poses a challenge to the efficient management. For efficient management and for the smooth flow of water it is required to have better institution for which more transaction cost is required. The productivity of the land also depend upon the physical condition of the canal system as well as the private investment by the farmers for the construction of the canal, repair and maintenance cost, location of the cultivated farm.

Since the study focusses on the institutional development and the transaction cost we examine the impact on production of factors like farm location, infrastructure quality, free riding, reliability of irrigation, transaction costs etc. There is much variation in the value of output and the cost of input among the studied irrigation systems. Thus attempt is made for the estimation of net return (total value of output-total production costs). Total production costs include the human labour cost, animal labour cost, and cost of the inputs, that is, chemical fertilizer, pesticides and seeds. In functional form, the model is:

Net return per hectare of output $=f$ (per hectare total transaction cost, reliability of irrigation, farm location, private investment, free riding, infrastructure quality)....

These variables are expected to impact on net farm income in different ways. The expected direction of these variables is presented in the Table 3. 
Table3: Definitions of Variables and Expected Signs

\begin{tabular}{|c|c|c|c|c|}
\hline $\begin{array}{l}\text { Factor } \\
\text { Context }\end{array}$ & $\begin{array}{l}\text { Variable } \\
\text { Name }\end{array}$ & $\begin{array}{l}\text { Definition of } \\
\text { Variable (Type: } \\
\text { continuous =C } \\
\text { Dummy=D) }\end{array}$ & $\begin{array}{l}\text { Expected } \\
\text { Impact on } \\
\text { productivity }\end{array}$ & Reason \\
\hline $\begin{array}{l}\text { Dependent } \\
\text { Variable }\end{array}$ & $\begin{array}{l}\text { net_prod_ } \\
\text { cost_ha }\end{array}$ & $\begin{array}{l}\text { Net Per hectare } \\
\text { return (Total Value } \\
\text { of output-Total } \\
\text { production cost) } \\
\text { (NRs) }\end{array}$ & & \\
\hline \multirow[t]{5}{*}{$\begin{array}{l}\text { Explanatory } \\
\text { Variables }\end{array}$} & tot_ha_tc & $\begin{array}{l}\text { Total Transaction } \\
\text { cost per hectare }\end{array}$ & +ve & $\begin{array}{l}\text { More time and effort for } \\
\text { the collection of water and } \\
\text { improvement in the reliability of } \\
\text { water availability for irrigation } \\
\text { in the field may result more } \\
\text { return from the field and have } \\
\text { positive impact on the return } \\
\text { on output. Similarly more time } \\
\text { and effort for institutional } \\
\text { development which is another } \\
\text { component of the TC may } \\
\text { also help for more return } \\
\text { from the agricultural field. }\end{array}$ \\
\hline & rel_irri & $\begin{array}{l}\text { Reliability of } \\
\text { irrigation facility } \\
\text { (D) }\end{array}$ & +ve & $\begin{array}{l}\text { More reliable the irrigation } \\
\text { facility more will the return } \\
\text { from crop in the farm. }\end{array}$ \\
\hline & $\begin{array}{l}\text { Locat_ } \\
\text { dum }\end{array}$ & $\begin{array}{l}\text { Location of the } \\
\text { farm } 1 \text { for Up and } \\
0 \text { for down } \\
\text { (D) }\end{array}$ & $+\mathrm{ve}$ & $\begin{array}{l}\text { It is assumed that farther the } \\
\text { farm location from the source of } \\
\text { the canal the water availability } \\
\text { will be low and output will also } \\
\text { be low. }\end{array}$ \\
\hline & pri_inv & $\begin{array}{l}\text { Private } \\
\text { Investment for the } \\
\text { construction of } \\
\text { the canal and well } \\
\text { defined property } \\
\text { rights (D) }\end{array}$ & +ve & $\begin{array}{l}\text { Private investment for the } \\
\text { construction of the canal and } \\
\text { well defined property rights } \\
\text { may have positive impact on } \\
\text { the institutional development } \\
\text { and for the return from the crop } \\
\text { in the land. }\end{array}$ \\
\hline & Infra_qua & $\begin{array}{l}\text { Quality of } \\
\text { infrastructure } \\
\text { quality (D) }\end{array}$ & +ve & $\begin{array}{l}\text { Better infrastructure quality } \\
\text { will result better reliability } \\
\text { of irrigation and hence more } \\
\text { return on output. }\end{array}$ \\
\hline
\end{tabular}


We anticipate that all the variables have positive impact on return from farm. In order to estimate the impact of the variables that affects the net return on output per hectare, the following multiple linear econometric model with OLS method is used.

net_prod_cost_ha $=\beta_{0}+\beta_{1}$ tot_ha_tc $+\beta_{2}$ pri_inv $+\beta_{3} r e l \_i r r i+\beta_{4}$ free_riding $+\beta_{5} i n f r a \_q u a+\beta_{6}$ locat_dum

\section{Regression Results}

Tables 4 and 5 show the summary statistics of the variables used in the regression and the output of the regression.

Table 4: Summary Statistics

\begin{tabular}{llllll}
\hline Variables & $\mathrm{N}$ & Mean & SD & Min & Max \\
\hline net_prod_cost_ha & 107 & 74779.5 & 68749.7 & -8133 & 281131 \\
tot_ha_tc & 93 & 2209.5 & 3119.7 & 0.00 & 17333.9 \\
pri_inv & 108 & 0.27 & 0.45 & 0.00 & 1.00 \\
rel_irri & 108 & 0.60 & 0.49 & 0.00 & 1.00 \\
free_riding & 108 & 0.64 & 0.48 & 0.00 & 1.00 \\
infra_qua & 108 & 0.54 & 0.50 & 0.00 & 1.00 \\
locat_dum & 108 & 0.50 & 0.50 & 0.00 & 1.00 \\
\hline
\end{tabular}

Table 5: Regression Results: Dependent Variable: net_prod_cost_ha

\begin{tabular}{lll}
\hline Explanatory Variables & Coefficient & Robust standard error \\
\hline tot_ha_tc & $4.77^{* * *}$ & 1.36 \\
pri_inv & $53293.12^{* * *}$ & 17238.73 \\
rel_irri & $40574.43^{* * *}$ & 16709.45 \\
free_riding & $36973.6^{* *}$ & 17721.11 \\
infra_qua & $29286.1^{* *}$ & 14578.87 \\
locat_dum & 5396.4 & 12432.46 \\
Intercept & -10246.5 & 19346.79 \\
$\mathrm{R}^{2}=0.2843$, Adjusted $\mathrm{R}^{2}=0.2344$ & & \\
\hline
\end{tabular}

** Significant at $5 \%$ level of significance, ${ }^{* * *}$ significant at $1 \%$ level of significance 
Regression result shows that the total transaction cost has a positive impact on the net return on output as expected. Similarly private investment has a significant positive impact on net return on output. When farmers contribute not only for the repair maintenance and management of the canal rather for the construction of canal and manage the canal with clearly defined property rights and suitable institutional settings, the net return on the farm increases significantly. This gives the ample reason in favor of the clearly defined property rights for successful of any institution.

Reliability of irrigation also has a significant positive impact on net return on output as expected. The coefficient of free riding is positive and significant. The free riders enjoy benefit of public good at the cost of other. This is one of the examples of classic dilemma of commons. Infrastructure quality also has positive and significant impact on net return on the farm output as expected.

The coefficient standard errors in Table 5 are based on the asymptotic approximations and may not be true when the sample size is small, as in our case. To overcome this, we use bootstrapping (Efron \&Tibshirani, 1993). There are two ways of bootstrapping a regression. The first approach assumesthat explanatory variables are random while the second approach treat these as fixed. The results in Figure 1 and Table 6 are obtained using the first approach where we set the sample size to be the observed sample size and number of replications to be 1000 .

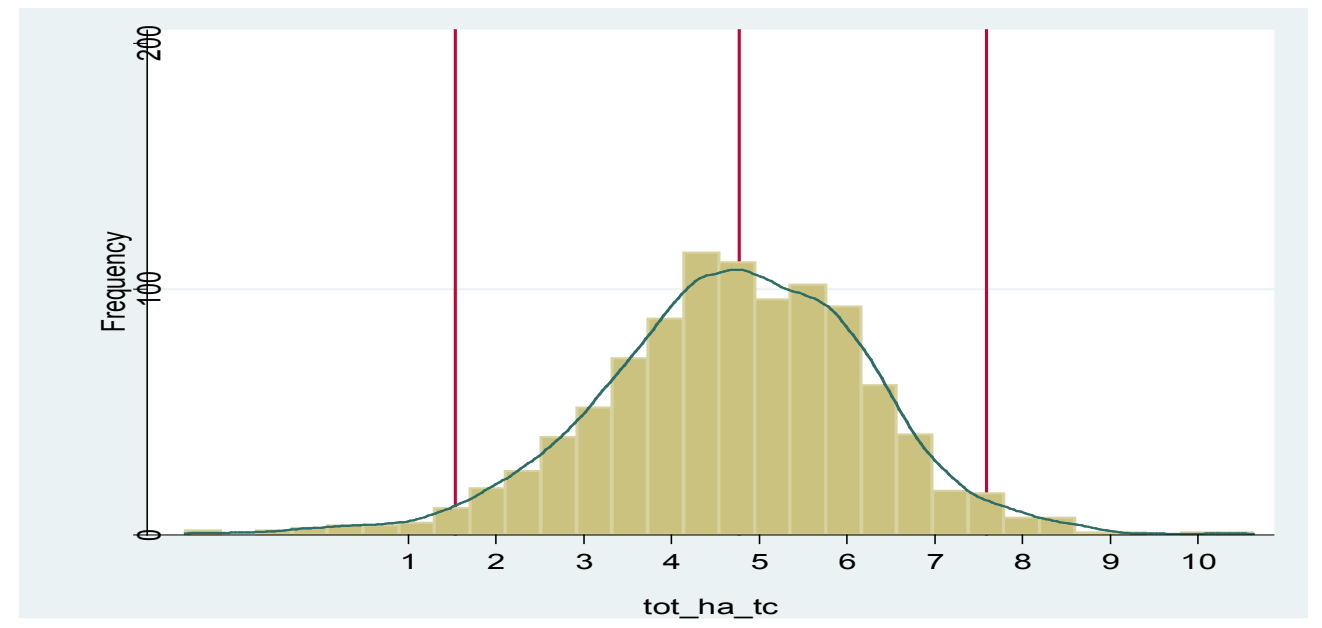

Figure 1: Distribution of the Bootstrapped Regression Coefficient for Total Transaction Cost 
The distribution of the bootstrapped regression coefficient for total transaction cost is shown in Figure 1 along with the percentile confidence interval for the coefficient. The distribution agrees with the normal. ${ }^{8}$ The bootstrap standard errors of the coefficients on total transaction cost and other explanatory variables are slightly larger than the asymptotic standard errors (Figure 1 and Table 6).

Table 6: Bootstrapping Regression Results

\begin{tabular}{llll}
\hline & \multicolumn{2}{l}{ Dependent Variable: net_prod_cost_ha } \\
Explanatory Variables & Coefficient & Bias & $\begin{array}{l}\text { Bootstrapped } \\
\text { standard error }\end{array}$ \\
\hline tot_ha_tc & $4.77^{* *}$ & 0.058 & 1.54 \\
pri_inv & $53293.12^{* * *}$ & 874.45 & 16755.21 \\
rel_irri & $40574.43^{* *}$ & -88.08 & 17502.30 \\
free_riding & $36973.6^{* *}$ & -421.72 & 17565.40 \\
infra_qua & $29286.1^{* *}$ & 355.84 & 14410.55 \\
locat_dum & 5396.4 & -278.84 & 12485.27 \\
Intercept & -10246.5 & 351.40 & 19717.89 \\
& $\mathrm{R}^{2}=0.2843$, Adjusted $\mathrm{R}^{2}=0.2344$ \\
\hline
\end{tabular}

** Significant at $5 \%$ level of significance, ${ }^{* * *}$ significant at $1 \%$ level of significance

Table 6 also shows that there is little bias in our original coefficient estimates. Moreover, the coefficients are still significant and so our original findings still holds.

\section{DISCUSSION AND CONCLUSION}

The study recorded the size and major components of transaction costs in FMIS in Hilly districts of Nepal. There are mainly five elements of transaction costs i.e. watching, waiting and negotiating cost, meeting cost, communication cost, conflict resolution cost and formation cost. Among these the share of watching, waiting and negotiating cost is about $70 \%$ followed by meeting cost $20 \%$ and formation cost $6 \%$ and conflict resolution cost $4 \%$. The communication cost is negligible. The share of total transaction cost is nearly $3 \%$ of the total cost of production and net farm return.

Per hectare transaction cost is highest to those households who do not contribute for the construction of the canal. On the other hand those households who invested for the

8 Similar result also holds for other explanatory variables. 
construction of the canal has lowest transaction cost per hectare. While comparing to the net return the share of transaction cost is lowest when water is more reliable. When farmers enjoy free riding transaction cost is high and when they control for free riding the share of transaction cost to net return is relatively low. The share of transaction cost to net return is high to those farmers located at downstream of the canal compared to those farmers located in upstream.

Those systems which give more time for the repair and maintenance of the canal also maintain the good quality of the canal. However, those who invest less in the repair and maintenance also have bad canal quality and low reliability of water. Reliability of irrigation also has a significant positive impact on net return on output as expected. Free riders have higher farm revenue as they have no obligation towards the irrigation management. The free riders enjoy benefit of public good at the cost of other. This justifies the existence of classic dilemma of commons. Infrastructure quality also has positive and significant impact on net return on the farm output as expected. Better infrastructure quality may help for more return from the farm. It is also clear that those who invest in both monetary and physical resources for the construction and repair and maintenance are able to manage the canal in better way with a clearly defined property rights. These systems are also able to generate more income from the farm.

This highlights that the private participation for the construction as well as for the management of the canal helps for the better performance of the canal and institution. On the other hand systems which were totally managed by the government and recently transferred to the users does not work properly since such system always seek the resources from the government for the repair and maintenance of the canal and they organize just for the purpose of seeking fund from the government organization.

Similarly well-defined rules also helps for the better performance of the canal. In some canals like Chherlung, Jethi and Maili Raj Kulo have well defined rules for the management and water distribution as well as repair and maintenance of the canal. There is a well-defined property right over the use of the canal water. Hence the regularity of the water flow is good, infrastructure quality is also good and hence the return from the canal is also better.

The findings also show that physical condition of the system also makes the system failure. For example when there is more rocky part and large land slides in the canal system it would be difficult in the part of the farmers to repair and renovate the canal. In such situation they need external help. To find the external help it needs coordination and approach to the central and local government. However, in the absence of strong and effective rules and regulation it becomes difficult to coordinate, organize and seek 
external support. Equity problem is also one of the causes of system failure. If all farmers irrespective of their irrigable land holdings should contribute equally, then farmers with small ownership are reluctant to participate.

Overall, the study suggests that transaction costs related to the setting up and running the water users association are low, that is, nearly $3 \%$ of the total cost of production and net farm return and in comparison to community forestry it seems to relatively low. Even though transaction costs are low, they contribute positively and significantly to net farm income. This shows that it makes some sense for farmers to contribute in the setting up and management of Water Users Association (an institution for the management of the irrigation canal).

One of the reasons for failure of system is the no proper rules of exclusion to nonmembers or non-contributors. Which results a free riding and hence a problem of common resources emerge and become difficult to manage the canal system. Bad decision of the government is also found as a reason of nonfunctioning of the canal. Government took over the management from the farmers and later hand over to the farmers without resources also contributed for the failure of the system. Farmers now feel that the management of the canal is the function of the government and it is not necessary to contribute for the construction of the canal. As such they are not ready to pay the fee to the water users committee and the water users committee formed for the management of the canal are just institution for the searching of external fund. Hence farmers' proper participation with well-defined rules and regulation can help for the better and sustainable management of FMIS in Nepal.

In systems which were managed by the government and transferred to the farmers, farmers have a feeling that all the cost for the repair and maintenance of the canal should be borne by the government. To change such feeling government should made mandatory provision of raising irrigation fee as per the land ownership. This may raise some fund and the water users committee may utilize such fee for the repair and maintenance of the canal.

New construction and repair and maintenance of the canal should be only with the real participation of the farmers. Government should make mandatory provision of raising irrigation fee as per the land ownership. This may raise some fund and the water users committee may utilize such fee for the repair and maintenance of the canal which may improve the reliability of the water to the farm and better productivity.

The regression model shows that the reliability of irrigation, infrastructure quality and private participation are much more important variable for the increase in net 
farm return. Hence the government should give emphasis for the improvement in the quality of the canal with the proper participation of the farmers.

\section{References}

Adhikari, B., \& Lovett, J. C. (2006). Transaction costs and community-based natural resource management in Nepal. Journal of Environmental Management, 78, 5-15.

Agrawal, A. (2001). Common property institutions and sustainable governance of resources. World Development, 29, 1649-1672.

APROSC. (1978). Irrigation impact evaluation study: Manusmara irrigation project. Kathmandu: Agricultural Projects Services Centre.

Bhattarai, R.C. (2007). Transaction costs in farmer managed irrigation systems in Nepal: A case study of some selected FMIS in Kathmandu Valley. In P. Pradhan et al (Eds.), Irrigation in Transition: Interacting with Internal and External Factors and Setting the Strategic Actions. Proceedings of the Forth International Seminar Held on 6-7 November 2006, Kathmandu, Nepal. Kathmandu: Farmer Managed Irrigation System Promotion Trust.

. (2011). Transaction matter but they hardly cost: Irrigation management in the Kathmandu Valley (SANDEE Working Paper, No 56-11). Kathmandu: South Asian Network for Environmental Economics (SANDEE).

Birner, R., \& Wittmer, H. (2000). Co-management of natural resources: A transaction cost economics approach to determine the 'efficient boundaries of the state'. Paper presented at the Annual Conference of the International Society of the New Institutional Economics (ISNIE) in Tubingen, Germany.

Bromley, D.W. (1989). Economic interest and institutions: The conceptual foundations of public policy. New York and Oxford: Basil Blackwell

CBS. (2011). Population census 2001: Selected economic activity tables. Kathmandu: Nepal Government, National Planning Commission Secretariat, Central Bureau of Statistics.

Dulal, S., \& Pradhan, P. (2002). Report on the inventory of irrigation systems in Kathmandu district, Nepal.

Efron, B., \& Tibshirani, R. J. (1993). An introduction to the bootstrap. New York: Chapman \& Hall.

Fenoaltea, S. (1984). Slavery and supervision in comparative perspectives: A model. Journal of Economic History,44, 635-668. 


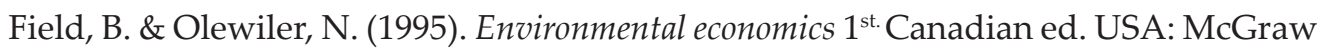
Hill and Ryerson.

Fukuyama, F. (1995). Trust: The social virtues and the creation of prosperity. New York: Free Press.

Hanna, S. (1995). Efficiency of user participation in natural resource management. In S. Hanna \& M. Manasinghe (Eds.),Property rights and the environment: Social and ecological issues (pp.59-67). Washington, DC: The Beijer International Institute of Ecological Economics and the World Bank.

Hayami, Y., \& Ruttan, V. W. (1985). Agricultural development: An international perspective. Baltimore: John Hopkins University Press.

Holloway, G., Nicholson, C., Delgado, C., Staal, S., \& Ehui, S. (2000). Agroindustrialization through institutional innovation: Transaction costs, cooperatives and milk-market development in the east-African highlands. Agricultural Economics, 23, 279-288.

Kuperan, K., Abdullah, N.M.R., Pomeroy, R.S., Genio, E.L., \& Salamanca, A.M. (1998, June10-14). Measuring transaction costs of fisheries co-management. Paper presented at the Seventh Biennial Conference of the International Association for the Study of Common Property, Vancouver, BC, Canada. Accessed from http://hdl.handle.net/10535/1876

Lam, W. F. (1998). Governing irrigation systems in Nepal. Oakland, California: Institute for Contemporary Studies.

. (2001). Coping with change: A study of local irrigation institutions in Taiwan. World Development, 29, 1569-1592.

Mburu, J., Birner, R., \& Zeller, M. (2003). Relative importance and determinants of landowners' transaction costs in collaborative wildlife management in Kenya: An empirical analysis. Ecological Economics, 45, 59-73.

MOF. (2015). Economic survey. Kathmandu: Ministry of Finance, Government of Nepal.

North, D.C. (1990). Institutions, institutional change and economic performance. Cambridge: Cambridge University Press.

NPC. (2002). Tenth plan 2002-2007.Kathmandu: Government of Nepal, National Planning Commission.

. (2007). Three year interim plan 2008-2011.Kathmandu: Government of Nepal, National Planning Commission. 
Osanami, F., \& Joshi, N.N. (2004).Farmer's incentives to participate in irrigation activities: Findings of case studies in Kathmandu Valley. In P. Pradhan \& U. Gautam (Eds.), Farmer managed irrigation systems and governance alternatives. Proceedings of the Third International Seminar Held on 9-10 September 2004, Kathmandu, Nepal. Kathmandu: Farmer Managed Irrigation Systems Promotion Trust.

Ostrom, E. (1990). Governing the commons: The evolution of institutions for collective action. Cambridge, New York: Cambridge University Press.

. (1992). Crafting institutions for self-governing irrigation systems. California: Institute for Contemporary Studies.

. (1994). Constituting social capital and collective action. Journal of Theoretical Politics, 6, 527-562.

Ruttan, V. W., \& Hayami, Y. (1984). Towards a theory of induced institutional innovation. Journal of Development Studies, 20, 203-223.

Saleth, R. M., \& Dinar, A. (2004). The institutional economics of water: A cross country analysis of institutions and performance. Cheltenham, UK and Northampton, MA, USA: Edward Elgar.

Senaratne, A., \& Karunanayake, K. (2006). Transaction costs and institutional innovation. Sustainability of Tank Aquaculture in Sri Lanka (SANDEE Working Paper No 1807). Kathmandu: South Asian Network for Development and Environmental Economics (SANDEE).

Sumalde, Z.M.,\& Pedroso, S.L. (2001).Transaction costs of community-based coastal resource management program in San Miguel Bay, Philippines. Economy and Environment Program for South East Asia (EEPSEA) Research Report.

Tang, S. Y. (1992). Institutions and collective action, Self-governance in irrigation. California: Institute of Contemporary Studies.

Uphoff, N.,\& Wijayaratna, C. M. (2000). Demonstrated benefits from social capital: The productivity of farmer organizations in Gal Oya, Sri Lanka. World Development, $28,1875-1890$.

Vandenberg, P. (2002). North's institutionalism and the prospect of combining theoretical approaches. CambridgeJournal of Economics, 26, 217-235.

Wade, R. (1988). Village republics: Economic conditions for collective action in South India. Cambridge: Cambridge University Press.

Williamson, O. E. (1975). Markets and hierarchies: Managerial objectives in a theory of the firm. New York: Free Press. 
(1979).Transaction-cost economics: The governance of contractual relations. The Journal of Law \& Economics, 22, 233-261.

. (1985).The economic institutions of capitalism: Firms, markets, relational contracting. New York: Macmillan.

(1991). Comparative economic organization: The analysis of discrete structural alternatives. Administrative Science Quarterly, 36, 269-296. 